\title{
FAKTOR GAYA HIDUP DENGAN KEJADIAN HIPERTENSI
}

\author{
Hanugrah Ardya $\mathrm{C}^{1}$, Ratika Marchelaona ${ }^{2}$, Atiek Murharyati ${ }^{3}$, Erinda Nur Pratiwi ${ }^{4}$ \\ Fakultas Ilmu Kesehatan Universitas Kusuma Husada Surakarta \\ E-mail : 'hanugrahardya8@gmail.com, ${ }^{2}$ marchela@ukh.ac.id, \\ ${ }^{3}$ murharyatiatik@gmail.com, ${ }^{4}$ pratiwierinda@gmail.com
}

\begin{abstract}
Hypertension is persistent blood pressure with systolic $>140 / 90 \mathrm{mmHg}$. One of the causes of hypertension is lifestyle, age and activity factors. The purpose of this study was to evaluate the incidence of hypertension in the community of Horaiquick Ainaro village, Maubessie Timor Leste. This study is an observational analytic study, with respondents in the age range 26-65 years. The sampling technique was carried out by observation and interviews. Data analysis was performed using univariate analysis. The results showed that there was no significant relationship between smoking lifestyle, coffee drinking habits and physical activity on the incidence of hypertension in the village of Horai Quick Ainaro Maubessie Timorleste.

Keywords: Hypertension, lifestyle, smooking, age
\end{abstract}

\begin{abstract}
ABSTRAK
Hipertensi adalah tekanan darah persisten dengan sistolik > 140/90 mmHg. Hipertensi salah satunya disebabkan oleh faktor gaya hidup, usia dan aktivitas. Tujuan penelitian ini adalah untuk mengevaluasi kejadian hipertensi di masyarakat desa Horaiquick Ainaro, Maubessie Timor Leste. Penelitian ini merupakan penelitian analitik obeservasional, dengan responden pada rentang usia 26-65 tahun. Teknik pengambilan sampel dilakukan secara observasi dan wawancara. Analisa data dilakukan dengan analisis univariat. Hasil penelitian menunjukkan bahwa tidak ada hubungan yang signifikan antara gaya hidup merpokok, kebiasaan minum kopi dan aktifitas fisik terhadap kejadian hipertensi di desa Horai Quick Ainaro Maubessie Timorleste
\end{abstract}

Kata Kunci: Hipertensi, Gaya Hidup, merokok, umur 


\section{PENDAHULUAN}

Hipertensi adalah tekanan darah tinggi diatas batas normal tekanan darah seseorang dan diukur paling tidak ada tiga kesempatan yang berbeda.

Healthy people 2010 for Hypertension menganjurkan perlunya pedekatan yang lebih komprehensif dan intensif guna mencapai pengontrolan tekanan darah secara optimal. Maka untuk mencapai tujuan tersebut diperlukan partisipasi aktif para sejawat apoteker yang melaksankan praktek profesinya pada setiap tempat pelayanan kesehatan dalam memberikan edukasi ke pasien mengenai hipertensi, memonitor respon pasien melelui farmasis komonitas. Adherence terhadap terapi obat dan non-obat, mendeteksi dan mengenali secara dini reaksi efek samping, serta mencegah atau memecahkan masalah yang berkaitan dengan pemberian obat untuk tujuan meningkatkan kepatuhan pasien terhadap terapi obat demi mencapai target tekanan darah yang diinginkan ${ }^{(8)}$.Kafein merupakan zat yang dapat mengatasi kelelahan dan meningkatkan konsentrasi serta menggembirakan suasana hati, Namun konsumsi kafein yang berlebihan dalam jangka yang panjang dan jumlah yang banyak diketahui dapat meningkatkan risiko penyakit hipertensi atau penyakit kardiovaskuler karena adanya peningkatan resistensi pembuluh darah tepi dan vasokontriksi disebabkan oleh kafein yang memiliki sifat antagonis endogenus adenosin. Peningkatan tekana darah dipengaruhi oleh dosis kafein yang biasa dikonsumsi oleh seseorang mempunyai efek yang rendah ${ }^{(11)}$.

Penyakit darah tinggi merupakan suatu gangguan pada pembuluh darah dan jantung yang mengakibatkan suplai oksigen dan nutrisi yang di bawah oleh darah terhambat sampai kejaringan yang membutuhkannya ${ }^{(10)}$.Tekanan darah tinggi berarti tekanan tinggi di dalam arteri-arteri. Arteri-arteri adalah pembuluhpembuluh yang mengangkut darah dari jantung yang memompa keseluruh jaringan dan organorgan tubuh (Pudiastuti, 2013).

\section{METODE}

Penelitian ini merupakan penelitian observasional dengan pendekatan cross sectional untuk menjelaskan hubungankausal antara variabel-variabel atau mempelajarai dinamika korelasi antara faktor-faktor risiko dengan cara pendekatan, observasi atau pengumpulan data sekaligus pada suatu saat.
Subyek penelitian adalah masyarakat desa Di Horai Quick Ainaro Maubessie Timorleste rentang umur 26-65 tahun. Penelitian dilkukan pada bulan Desember 2019. Pengambilan data dilakukan dengan metode kuisioner dan wawancara langsung kepada responden yang meliputi (jenis kelamin, kelompok umur, tingkat pendidikan, bidang pekerjaan, riwayat hipertensi keluarga, aktivitas fisik)

\section{HASIL}

Karaterikstik Responden

Penelitian dilkukan di Desa Horai-Quick Ainaro Maubessie Timor leste pada bulan Desember 2019 dengan jumlah responden 35 responden, dari 35 responden jumlah pasien laki -laki 17 (49\%) dan perempuan 18 (51\%), kelompok umur 26-35 tahun 4 (11,5\%), $36-$ $4512(34,2 \%)$ 46- 55 tahun $14(40 \%)$ 56-75 tahun $5(14.3 \%)$.

Tabel 1 Karateristik Responden

\begin{tabular}{|l|c|c|}
\hline Jenis Kelamin & $\mathrm{n}$ & $\%$ \\
\hline Laki-laki & 17 & 49 \\
\hline Perempuan & 18 & 51 \\
\hline Umur & $\mathrm{n}$ & $\%$ \\
\hline 36-45 tahun & 4 & $11.5 \%$ \\
\hline 66-55 tahun & 12 & $34.2 \%$ \\
\hline 56-65 tahun & 14 & $40 \%$ \\
\hline Pendidikan & 5 & $14.3 \%$ \\
\hline SD & $\mathrm{n}$ & $\%$ \\
\hline SMP & 10 & $28.6 \%$ \\
\hline SMA & 12 & $34.3 \%$ \\
\hline Srata 1 & 9 & $25.7 \%$ \\
\hline Tipertensi & 4 & $11.4 \%$ \\
\hline Tidak & 31 & $88.5 \%$ \\
\hline
\end{tabular}

\section{Variabel penelitian}

Data penlitian meliputi penyakit hipertensi, merokok, minum kopi dan aktivitas fisik dapat dilihat pada tabel 2 berikut 


\begin{tabular}{|l|c|c|}
\hline Hipertensi & $\mathrm{n}$ & $\%$ \\
\hline Ya & 6 & $17.2 \%$ \\
\hline Tidak & 29 & $82.8 \%$ \\
\hline Status Merokok & $\mathrm{n}$ & $\%$ \\
\hline Ya & 18 & $51.5 \%$ \\
\hline Tidak & 17 & $48.5 \%$ \\
\hline Minum Kopi & $\mathrm{n}$ & $\%$ \\
\hline Sering & 23 & $65.8 \%$ \\
\hline Jarang & 12 & $34.2 \%$ \\
\hline Aktivitas Fisik & $\mathrm{n}$ & $\%$ \\
\hline Cukup & 30 & $85.7 \%$ \\
\hline Kurang & 5 & $14.3 \%$ \\
\hline
\end{tabular}

\section{PEMBAHASAN}

Pada penelitian ini menunjukkan sebagian besar responden mempunyai jenis kelamin perempuan yaitu sebanyak 18 (51) dan laki-laki 17 (49). Hasil analisis gambaran antara jenis kelamin dengan kejaian hipertensi dapat diketahui bahwa persentase kejadian hipertensi lebih banyak terjadi pada perempuan dibanding laki-laki. Pada penelitian lain menyebutkan bahwa perempuan lebih banyak menderita hipertensi dikarenakan perempuan mengalami menopause terjadi perubahan hormonal yaitu terjadi penurunan perbandinagn esterogen dan androgen yang menyebabkan peningkatan pelepasan renin, sehingga memicu tekanan darah $^{(7)}$. Pada penelitain ini menunjukkan bahawa respondem berada pada rentan usia antara 25- 65 tahun. Usia termuda 26 tahun sedangakan usia tertua adalah 65 tahun. Hasil penelitian menunjukkan bahwa respon yang menderita hipertensi lebih banyak pada usia 46- 55 tahun yakni sebanyak $40 \%$. Hal sejalan dengan teori dari riskesdas tahun 2007 dengan bertambahnya umur maka tekanan darah akan meningkat. Setelah umur 45 tahun akan mengalami penebalan oleh karena adanya penumpukan zat kolagen pada lapisan otot sehingga pembuluh darah akan berangsurangsur menyempit dan menjadi kaku.

Berdasarkan hasil penelitian menunjukkan bahwa pendidikan terakhir responden pada tingkat strata 1 yakni sebanyak $11.4 \%$ dan terendah tingkat pendidikan SD 28.6\%

Dari hasil penelitian di desa Horai Quick Ainaro Maubessie menunjukkan meskipun pendidikan starta 1 tapi masyarakat masih tidak memahami faktor resiko terjadinya hipertensi.

bidang pekerjaan untuk masyarakat desa HoraiQuick Ainaro adalah sebgaian besar berprofesi sebagai petani dan ibu rumah tangga

Hasil penelitian menunjukkan bahwa sebagian besar responden adalah petani $57.2 \%$ dan ibu rumah tangga $28,5 \%$, guru $8.6 \%$, swasta $5,7 \%$.Pada penelitian ini menunjukkan bahwa sebagian besar responden tidak memiliki keluarga hipertensi sebanyak $88.5 \%$ dan yang tidak memiliki keluarga hipertensi sebanyak 11.5\%.Hasil penelitian menunjukkan bahwa prevalensi responden yang menderita hipetensi lebih sedikit yaitu $17.2 \%$ dibandingkan yang tidak hipertensi $82.8 \%$. Rata-rata tekanan darah sistolik responden adalah $125 \mathrm{mmHg}$ sedangkan rata-rata tekanan darah diastolik responden adalah $78 \mathrm{mmHg}$. Tekanan sistolik paling tinggi mencapai $189 \mathrm{mmHg}$ sedangkan diastoliknyta $100 \mathrm{mmHg}$. Menurut JNC VII, seseirang dikatakan hipertensi jika tekanan darah sistoliknya $>140 \mathrm{mmHg}$ dan tekana darah diastoliknya > $90 \mathrm{mmHg}^{(9)} \mathrm{Hasil}$ penelitian ini menunjukkan bahwa tidak ada hubungan yang signifikan antara kebiasaan merokok dengan kejadian hipertensi ${ }^{(2)}$

Kebiasaan mengkonsumsi kopi bagi warga desa Horai-Quick Ainaro sudah menjadi kebiasaan baik bagi lai-laki maupun perempuan dimana mereka mengkonsumsi kopi bisa lebih dari $5 \mathrm{x}$ perhari.Aktivitas fisik pada penelitian ini diukur menggunakan pedometer dengan kategori cukup apabila> 7000 langkah/ hari. Hasil penelitian ini menunjukkan bahwa tidak ada hubungan yang signifikan antara aktivitas fisik dengan kejadian hipertensi. Dimana responden warga Horai-Quick Ainaro sebagian besar warga masyarakat berprofesi sebagai petani dimana dari rumah ke ladang mereka jalan kaki dan masyaraat warga desa Ainaro masih banyak yang mengandalkan jalan kaki sehingga aktivitas fisik masyarakat disana lebih dari 1000 langkah per hari.

\section{KESIMPULAN}

Tidak ada hubungan yang signifikan antara gaya hidup merokok, kebiasaan minum kopi dan katifitas fisik terhadap kejadian hipertensi di Desa Horai Quick Ainaro Maubessie Timor Leste.

\section{DAFTAR PUSTAKA}

1. Armilawaty, Amalia H, Amirudin R., 2007. Hipertensi dan Faktor Resikonya dalam kajian Epidemiologi. Bagian Epidemiologi 
FKM UNHAS, Cermin Dunia Kedokteran, $15(3)$

2. Amu, D.A. 2015. "Faktor- Faktor yang Memepengaruhi Hipertensi di wilayah Perkotaan dan pedesaan di Indonesia Tahun 2013". Skripsi. Jakarta: Fakultas Kedokteran dan Ilmu Kesehatan Universitas Islam Negeri Syarif Hidayatullah.

3. Anies. 2006. Ancaman Penyakit Tidak Menular. Jakarta: PT Gramedia.

4. Bustan. M.N. 2007. Epidemiologi Penyakit Tidak Menular. Jakarta: PT Rineka Cipta

5. Casey, A dan Benson, H. 2006. Menurunkan Tekanan Darah. Jakarta: PT Bhuanha Ilmu Populer.

6. CDC. 2016. " Healthy Living : Physical Activity and Exercise".

7. Coylewright $\mathrm{M}$, Keith $\mathrm{C}$ Ferdinand, MD, 2008, Clinical Profesor, Cardiology Division Emory University Chief Science Officer
Association of Black Cardiologist, Inc. Atlanta, GA2008, Assessment of Cardiovascular Risk Factors in Post menopausal Women, 51 :952

8. Depkes RI, 2007. Pharmaceutical Care untuk Penyakit Hipertensi, Pedoman Konseling Pelayanan Kefarmasian di Sarana Kesehatan. Direktorat Jendral Bina Farmasi, Jakarta

9. Kemenkes RI. 2014. Riset Kesehatan Dasar (RISKESDAS) 2013. Jakarta : Kementrian Kesehatan RI.

10. Pudiastuti, D. 2013. Penyakit-Penyakit Mematikan. Yogyakarta: Nuha Medika

11. Wahyuni, Tri. (2013). Hubungan Konsumsi Kopi Dengan Tekanan Darah Pada Pasien Rawat Jalan Puskesmas Bogor Tengah. Bogor: Departemen Gizi 